\title{
Kajian Pelaksanaan Penyuluhan dan Partisipasi Perempuan pada Kegiatan Pertanian Tanaman Palawija di Desa Suka Damai, Kecamatan Dramaga, Kabupaten Bogor
}

\section{The study of the implementation studies of extension and and women's participation in Agricultural Crops Activity in Suka Damai Village, District Dramaga, Bogor Regency}

\author{
Hayati Zakaria ${ }^{1}$ \\ ${ }^{1}$ Fakultas Pertanian, Universitas Mataram, Nusa Tenggara Barat
}

\begin{abstract}
The study of the implementation studies of extension and women's participation in Agricultural Crops Activity in Sukadamai Village, District Dramaga, Bogor Regency aimed to analyze the level of women participation in agricultural crops activity; to analyze the level of women participation in agricultural crops extension activities; to identify the institusional of agricultural extension; to analyze the influence factor in the ability of the extension worker to improve women's participation in agricultural crops extension activities. Sampling was done randomly respondents. Number of study sample as many as 30 people. Primary data obtained through the use of closed questionnaires, interviews with the use of an open questionnaire, focus group discussion (FGD), and observations. Stages of data analysis is divided into stages of data description and hypothesis testing phase. Results showed that the women participation in agricultural crops extension activities in high category is 53,3\%; the women participation in agricultural extension activities in the low category is 50\%; the existence of agricultural extension workers is recognized by women are civil servants extension workers and independent extension workers; the method of agricultural extension and the attidude of extension workers affect significantly $(p<0,05)$ to women's participation in agricultural extension activities.
\end{abstract}

Keywords: participation, agricultural extension, agricultural crops activity, the institusional of agricultural extension

\begin{abstract}
Abstrak
Kajian Pelaksanaan Penyuluhan dan Partisipasi Perempuan pada Kegiatan Pertanian Tanaman Palawija di Desa Suka Damai, Kecamatan Dramaga, Kabupaten Bogor ditujukan untuk menganalisis tingkat partisipasi perempuan dalam kegiatan pertanian tanaman palawija, menganalisis tingkat partisipasi perempuan dalam kegiatan penyuluhan pertanian tanaman palawija, mengidentifikasi kelembagaan penyuluhan apa saja yang berperan dalam kegiatan penyuluhan pertanian tanaman palawija, menganalisis pengaruh faktor kemampuan penyuluh dalam meningkatkan partisipasi perempuan dalam kegiatan penyuluhan pertanian tanaman palawija. Jumlah responden penelitian sebanyak 30 orang yang ditentukan secara random. Data primer dikumpulkan melalui wawancara yang menggunakan kuisioner tertutup, waawancara dengan menggunakan kuisioner terbuka, focus group discussion (FGD), dan observasi. Tahapan analisis data adalah terdiri dari deskripsi data dan uji hipotesis. Hasil penelitian bahwa perempuan yang memiliki partisipasi yang tinggi dalam melakukan pekerjaan pertanian tanaman palawija sebanyak 50\%, partisipasi perempuan dalam kegiatan penyuluhan pertanian tanaman palawija dalam kategori rendah sebanyak 53,3\%; keberadaan penyuluh yang diakui oleh perempuan adalah PPL PNS, dan penyuluh swadaya; faktor kemampuan penyuluh dalam melaksanakan penyuluhan yang mempengaruhi partisipasi perempuan dalam kegiatan penyuluhan adalah peubah metode dan sikap penyuluh $(\mathrm{p}<0,05)$ yang berpengaruh secara nyata.
\end{abstract}

Kata kunci: partisipasi, penyuluhan pertanian, kegiatan pertanian tanaman pangan, kelembagaan penyuluhan pertanian

\section{Pendahuluan}

Perempuan petani terus memainkan peran yang menentukan dalam pembangunan pertanian tanaman pangan. Namun, perempuan petani semakin menghadapi tantangan di era globalisasi dalam perdagangan pertanian, memenuhi kebutuhan produksi tanaman pangan bagi penduduk yang terus bertambah, adanya perkembangan informasi pertanian yang cepat dan teknologi komunikasi (FAO, 1996; LEISA Editorial, 2000). Banyak hasil studi yang menegaskan pentingnya partisipasi perempuan dalam kegiatan pertanian dan produksi makanan (Chizari M et al., 1997; Damisa et al., 2007; Elizabeth S, 2007; FAO, 2009; Oladejo et al,. 2011; Poats, 1990). Selain temuan bahwa perempuan petani melakukan kegiatan pertanian tanaman pangan di samping kegiatan rumah tangga, bukti-bukti empiris dari studi di berbagai Negara juga menunjukkan bahwa penyuluhan pertanian pada perempuan petani masih kurang dan perlu dilakukan.

Pengabaian perempuan petani dalam kegiatan penyuluhan pertanian masih saja terjadi meskipun upaya untuk meningkatkan partisipasi perempuan 
petani dalam penyuluhan pertanian telah lama dilakukan (Elizabeth S, 2007; Hayati, 2000, Jiggins, 1997; Mudukuti, 2002; Pini, 2002; Rivera, 1990; Shibanda dan Seru, 2002; Squire PJ, 2003; Suradkar, 2010). Padahal dengan memberikan kesempatan bagi perempuan untuk mengikuti kegiatan penyuluhan pertanian sangat penting dan tidak hanya dipandang sebagai hal yang lumrah dan baik melainkan juga untuk mewujudkan kesetaraan akses dan partisipasi perempuan pada kegiatan penyuluhan, pendidikan atau pelatihan, serta hal mendasar sebagai pemenuhan hak azasi perempuan sebagai manusia (Chizari et al., 1997; Squire PJ, 2003). Berdasarkan pendapat dari para peneliti terkait dengan partisipasi perempuan dalam kegiatan penyuluhan pertanian, pengertian penyuluhan pertanian (agricultural extension) adalah sebagai suatu sistem pendidikan luar sekolah untuk para petani dan keluarganya tanpa batasan umur dan tanpa perbedaan kelamin. Materi penyuluhan ditentukan berdasarkan kebutuhan sasaran penyuluhan baik laki-laki maupun perempuan. Tujuan jangka pendeknya adalah berusaha untuk mengubah perilaku (sikap, tindakan dan pengetahuan) klien dalam menghadapi tantangan dan memecahkan berbagai permasalahannya secara mandiri maupun berkelompok, mengubah perilaku klien ke arah yang lebih baik lagi; dan tujuan jangka panjangnya adalah guna terwujudnya peningkatan kualitas hidup petani ke arah yang diidealkan.

Namun, pengabaian perempuan dalam kegiatan penyuluhanpertanianmasihsajaterjadi.Halinidisebabkan oleh factor-faktor yang dapat berasal dari hambatan internal dan eksternal termasuk hambatan kelembagaan (Richardson JG et al., 2003). Hambatan kelembagaan dalam hal ini adalah faktor yang berhubungan dengan kelembagaan (lembaga penyuluhan) yang menyurutkan partisipasi atau "semua praktek dan prosedur yang mencegah orang dewasa untuk berpartisipasi dalam kegiatan pelatihan/pendidikan/penyuluhan" Beberapa hasil penelitian menemukan bahwa faktor yang terkait dengan kelembagaan penyuluhan telah terbukti dapat mem-pengaruhi partisipasi perempuan dalam kegiatan penyuluhan pertanian (Akeredolu, 2009; Goff S et al., 2008; Jiggins, 1997; Mudukuti, 2002; Pini, 2002; Squire PJ, 2003; Suradkar, 2010).

Di Indonesia, partisipasi perempuan pedesaan pada pertanian tanaman pangan, khususnya tanaman palawija belum dipandang sebagai potensi yang dapat dikembangkan agar dapat bermanfaat bagi dirinya, keluarganya serta masyarakat. Perempuan petani masih belum dipandang sebagai "petani" melainkan hanya sebagai "pembantu suami dalam melakukan pekerjaan di lahan pertanian". Pandangan ini berimplikasi pada terbatasnya akses perempuan petani terhadap informasi pertanian dalam bentuk pelatihan maupun penyuluhan (Hayati, 2000; Hayati et al., 2003; Sudarta, Windia dan Gunarsa dalam Palupi, 1998; Supartiningsih et al., 1997; Surayasa, 1998, Wahyuni, 2008). Di sisi lain, untuk mencapai keberhasilan pembangunan pertanian yang berkelanjutan dan efisien, hendaknya kaum perempuan petani dikembangkan potensinya melalui peningkatan partisipasinya mulai dari tahap proses pengambilan keputusan tentang rencana kegiatan, tahap pelaksanaan kegiatan, tahap evaluasi kegiatan dan tahap menikmati hasil dalam kegiatan pertanian tanaman palawija dan penyuluhan pertanian tanaman palawija (Cohen dan Uphoff, 1977). Peran kelembagaan dalam hal ini kelembagaan penyuluhan baik itu lembaga pemerintah, swasta ataupun swadaya masyarakat merupakan lembaga yang penting untuk meningkatkan partisipasi perempuan petani dalam kegiatan pertanian dan penyuluhan pertanian.

Desa Suka Damai merupakan salah satu desa di Kecamatan Dramaga Kabupaten Bogor di mana sektor pertanian adalah salah satu sumber lapangan pekerjaan bagi penduduk Desa Suka Damainya. Sejalan dengan temuan di atas (Hayati, 2000; Hayati et al., 2003; Sudarta, Windia dan Gunarsa dalam Palupi, 1998; Supartiningsih etal., 1997; Surayasa, 1998; Wahyuni, 2008), berdasarkan hasil observasi dan wawancara terhadap ketua Gapoktan Agrisilvo dan perempuan petani pada survey pendahuluan, diperoleh informasi bahwa perempuan di Desa Suka Damai Kecamatan Dramaga Kabupaten Bogor tidak hanya terlibat dalam kegiatan pertanian tanaman pangan melainkan juga dalam mengambil keputusan terkait dengan kegiatan usaha tani tanaman palawija. Namun, pekerjaan perempuan sebagai petani telah dipandang sebelah mata oleh kaum laki-laki atas partisipasinya pada kegiatan pertanian tanaman palawija. Persepsi petani lakilaki yang negatif terhadap partisipasi perempuan dalam kegiatan pertanian membuat peran perempuan tidak nampak dan tidak penting, serta diabaikan dalam kegiatan penyuluhan pertanian. Mengacu pada temuan penelitian yang dilakukan oleh Akeredolu (2009), Goff S et al. (2008), Jiggins (1997), Mudukuti (2002), Pini (2002), Squire PJ (2003), dan Suradkar (2010), kondisi tersebut mengindikasikan lemahnya dan gagalnya lembaga penyuluhan, pendidikan, dan pelatihan yang ada dalam mengadaptasi penyuluhan, pendidikan, dan pelatihan 
bagi perempuan. Dengan demikian, diduga bahwa factor kelembagaan mempengaruhi partisipasi perempuan petani dalam kegiatan penyuluhan pertanian tanaman palawija di Desa Suka Damai Kecamatan Dramaga

Pengingkaran terhadap partisipasi perempuan dalam kegiatan produksi pertanian tanaman palawija yang berdampak pada pengabaian perempuan dalam kegiatan penyuluhan pertanian di Desa Suka Damai Kecamatan Dramaga merupakan permasalahan utama yang dihadapi perempuan sebagai petani untuk mengembangkan potensi yang dimilikinya. Oleh karenanya perumusan masalah dalam penelitian ini adalah Bagaimanakah partisipasi perempuan petani dalam kegiatan pertanian dan kegiatan penyuluhan pertanian tanaman palawija di Desa Suka Damai, dan bagaimanakah pelaksanaan kegiatan penyuluhan pertanian tanaman palawija di Desa Suka Damai?

Tidak bisa dipungkiri bahwa keberhasilan pembangunan nasional amat ditentukan oleh partisipasi masyarakat, bahkan menurut Roger (1994), pembangunan itu sendiri adalah partisipasi. Pendapat ini juga didukung oleh Slamet (2003), yang mengemukakan bahwa indikator keberhasilan pembangunan bisa diukur dari ada tidaknya partisipasi masyarakat. Sudah lama esensi partisipasi dijadikan indikator pembangunan. Mengenai hal ini, Siti Amanah (2006) mengemukakan bahwa partisipasi menjadi indikator dari istilah pembangunan masyarakat yang digunakan pertama kali pada tahun 1930 di AS dan Inggris. Pernyataan-pernyataan ini juga sejalan dengan apa yang dikemukakan oleh Jaringan PBB untuk pembangunan pedesaan dan keamanan pangan sebagai berikut: "...describes participation as one of the ends as well as one of the means of development.' Dengan demikian, partisipasi erat hubungannya dengan kaitan pembangunan, baik itu pembangunan dari dalam masyarakat itu sendiri maupun pembangunan dari luar masyarakat/pemerintah.

Beberapa penelitian tentang partisipasi perempuan dalam pembangunan menggunakan konsep partisipasi sebagai keterlibatan perempuan dalam pelaksanaan kegiatan pembangunan (Akeredolu, 2009; Barbercheck M et al., 2009; Chizari et al., 1997; Oladejo et al., 2011; Richardson JG et al., 2003; Squire PJ, 2003; Strong dan Harder, 2010; Vatta, et al., 2008; Yazdani et al., 2011). Sementara itu, pendapat lain bahwa partisipasi adalah keterlibatan perempuan dalam mengambil keputusan (Goff S et al., 2008). Sedangkan Barbercheck M et al. (2009) menggunakan konsep partisipasi untuk menyatakan keterlibatan perempuan petani dalam pembangunan dan perencanaan program penyuluhan. Namun, secara lebih luas dikatakan bahwa partisipasi perempuan dalam pembangunan tidaklah sebatas pada keterlibatan perempuan dalam pelaksanaan program atau pengambilan keputusan melainkan keterlibatan perempuan dalam tahapan pembangunan yang dipilah ke dalam perencanaan, pelaksanaan, dan evaluasi (Squire PJ, 2003; Yazdani et al., 2011).

Pendapat yang lebih luas dikemukakan oleh Cohen dan Uphoff (1977) yang mengatakan bahwa partisipasi tidak saja merupakan keterlibatan aktif masyarakat dalam proses pengambilan keputusan tentang apa yang akan dilakukan dan bagaimana cara kerjanya; dalam pelaksanaan program dan keputusan yang telah ditetapkan melalui sumbangan sumberdaya atau bekerja sama dalam suatu organisasi dan evaluasi, melainkan juga kerlibatan masyarakat menikmati manfaat dari pembangunan itu sendiri. Definisi tersebut mengacu pada pengertian bahwa partisipasi sebagai keterlibatan aktif masyarakat mulai dari tahap proses pengambilan keputusan tentang rencana kegiatan, tahap pelaksanaan kegiatan, tahap menikmati hasil dan tahap evaluasi pelaksanaan kegiatan.

Partisipasi perempuan petani dalam kegiatan pembangunan pertanian hendaknya tidak hanya sekedar melibatkan perempuan petani pada pelaksanaan kegiatan pembangunan saja, atau pada perencanaan saja, atau pada perencanaan, pelaksanaan dan evaluasi tanpa melihat apakah perempuan petani mendapatkan manfaat dari partisipasinya pada ke tiga tahapan tersebut. Sebaiknya, partisipasi perempuan petani harus meliputi keterlibatan aktif perempuan pada seluruh tahapan yaitu: tahapan perencanaan, pelaksanaan, evaluasi dan juga dalam memperoleh manfaat dari pembangunan itu sendiri. Hal ini mencerminkan sejauhmana perempuan petani dipandang sebagai subjek pembangunan yang penting dan bagaimana keberhasilan pembangunan pertanian yang telah dilakukan. Hal ini mendukung pendapat Roger (1994) dan Slamet (2003) bahwa bahwa indikator keberhasilan pembangunan bisa diukur dari ada tidaknya partisipasi masyarakat.

Petani baik perempuan dan laki-laki memainkan peran penting dalam pertanian di seluruh dunia, memproduksi, mengolah dan menyediakan makanan yang dimakan manusia. Jumlah perempuan merupakan setengah populasi penduduk pedesaan dan lebih dari setengah mereka bekerja sebagai tenaga kerja pertanian. Selain itu, perempuan di pedesaan juga bertanggung 
jawab atas setengah dari dunia produksi pangan dan menghasilkan antara $60 \%$ dan $80 \%$ dari makanan di kebanyakan negara berkembang. Namun, meskipun perempuan memberikan kontribusi yang besar terhadap keamanan pangan global, perempuan petani sering diremehkan dan diabaikan dalam pengembangan strategi pembangunan. Perempuan petani seringkali dipandang bukan sebagai petani, melainkan hanya membantu pekerjaan suami (Afzal, 2010; FAO, 2009; Oladejo et al., 2011).

Komponen yang mendukung rendahya partisipasi perempuan dalam kegiatan penyuluhan pertanian adalah komponen perencanaan, pelaksanaan, pengawasan dan manfaat yang juga berada pada kategori rendah. Rendahnya pelaksanaan juga karena perempuan hanya terlibat sebagai peserta penyuluhan saja, tetapi rendah partisipasinya dalam hal kegiatan administrasi dan koordinasi.

Chizari et al. (2003) dan Damisa et al. (2007) mengatakan bahwa berbagai penelitian tentang kontribusi perempuan dalam pembangunan pertanian menunjukkan bahwa kontribusi perempuan dalam kerja pertanian adalah tinggi yaitu antara $60 \%$ dan $90 \%$ dari total tugas pertanian yang dilakukan. Kontribusi perempuan adalah melakukan tugas-tugas seperti membersihkan tanah, mengolah tanah, menanam, menyiangi,memupuk,memanen, mengolahmakanan, mengirik, menampi, penggilingan,transportasi dan pemasaran serta pengelolaan ternak. Pentingnya peran yang dimainkan oleh perempuan pada produksi pertanian tersebut dipandang sama pentingnya dengan gagalnya penyuluhan pertanian yang mengikutsertakan perempuan petani karena akan memiliki dampak besar bagi pendapatan nasional dan ketahanan pangan serta keadilan sosial (Oladejo et al., 2011). Pengabaian perempuan petani dalam kegiatan penyuluhan pertanian masih saja terjadi meskipun upaya untuk meningkatkan partisipasi perempuan petani dalam penyuluhan pertanian telah lama dilakukan (Hayati, 2000; Jiggins, 1997; Mudukuti, 2002; Pini, 2002; Rivera, 1990; Shibanda dan Seru, 2002; Suradkar, 2010).

Jiggins (1997), dan Pini (2002) menemukan bahwa pelatihan sering dilakukan di pusat pelatihan di mana pusat pelatihan petani terlihat sangat "male bias" atau "masculine culture". Proses yang berlangsung selama kegiatan selalu berpihak kepada laki-laki. Pertemuan dipandang sebagai " boy's club' karena sangat didominasi oleh peserta laki-laki. Kondisi ini menyebabkan bahasa, sikap dan tindakan yang terjadi selama proses kegiatan sangat "sexism", pendapat perempuan selalu diabaikan, tidak mampu menumbuhkan semangat perempuan, dan akhirnya perempuan merasa tidak diharapkan hadir di tempat itu. Mudukuti (2002) dan Pini (2002) juga menemukan faktor kurangnya dukungan. Kurangnya dukungan terhadap perempuan dapat berasal dari suami, keluarga, masyarakat dan perempuan lain.

Faktor lainnya adalah berkaitan dengan bagaimana kegiatan dilaksanakan, waktu dan tempat kegiatan. Hal ini dapat ditunjukkan dengan waktu pertemuan yang terlalu lama, membosankan, proses pelaksanaan yang kurang baik, pertemuan terlalu formal, "team work" yang tidak memadai, waktu dimulainya kegiatan, dan tempat yang tidak tepat bagi perempuan karena jauh dari rumah (Mudukuti, 2002; Pini, 2002). Faktor sosial dan adat budaya mencegah perempuan pedesaan untuk hadir pada kegiatan penyuluhan, beban ganda perempuan yaitu menjalankan peran domestik dan peran di lahan pertanian (Akeredolu, 2009; Jiggins, 1997; Mudukuti, 2002; Pini, 2002), keyakinan agama (Akeredolu, 2009; Chizari et al., 1997), pegembangan program dan materi penyuluhan tidak sesuai dengan kebutuhan perempuan petani (Mudukuti, 2002; Pini, 2002), tidak ada lahan atau akses terhadap lahan (Mudukuti, 2002), hak milik dan hukum warisan (Jiggins, 1997). Selain itu, persepsi masyarakat bahwa perempuan bukan sebagai petani (Akeredolu, 2009; Squire PJ, 2003), berlakunya pembagian kerja berdasarkan jender dimana perempuan melakukan pekerjaan rumah tangga, sedangkan laki-laki mencari nafkah (Akeredolu, 2009; Jiggins, 1997). Faktor lain yang turut mempengaruhi partisipasi atau keterlibatan/ kehadiran perempuan adalah umur atau penglihatan yang buruk, tidak konsisten/bersedia turut belajar, sibuk mencari uang dengan melakukan pekerjaan tambahan di kota (Vatta et al., 2008); motivasi belajar (Strong dan Harder, 2010), kurang tersedianya transportasi, kurangnya informasi tentang kegiatan penyuluhan dan kurangya akses perempuan terhadap kredit, ketidakmampuan perempuan untuk membaca dan menulis, kurangnya penyuluh perempuan (Mudukuti, 2002), kurangnya fasilitas perawatan anak (Mudukuti, 2002; Jiggins, 1997).

Berdasarkan uraian di atas, maka masalah yang ditelaah sebagai pertanyaan penelitian adalah: 1) bagaimanakah tingkat partisipasi perempuan petani dalam kegiatan pertanian tanaman palawija; 2) bagaimanakah 
tingkat partisipasi perempuan dalam kegiatan penyuluhan pertanian tanaman palawija?; 3) kelembagaan penyuluhan apa saja yang berperan dalam kegiatan penyuluhan pertanian tanaman palawija; 4) bagaimanakah pengaruh factor kelembagaan penyuluhan terhadap partisipasi perempuan dalam kegiatan penyuluhan pertanian tanaman palawija?

Berdasarkan permasalah, tujuan penelitian ini adalah: 1) menganalisis tingkat partisipasi perempuan petani dalam kegiatan pertanian tanaman palawija; 2) menganalisis tingkat partisipasi perempuan dalam kegiatan penyuluhan pertanian tanaman palawija; 3) mengidentifikasi kelembagaan penyuluhan apa saja yang berperan dalam kegiatan penyuluhan pertanian tanaman palawija; 4) menganalisis pengaruh faktor kelembagaan penyuluhan terhadap partisipasi perempuan dalam kegiatan penyuluhan pertanian tanaman palawija?

\section{Metode Penelitian}

Jenis penelitian yang digunakan dalam penelitian ini adalah penelitian deskriptif explanatory (Singarimbun dan Effendi, 1989), yaitu jenis penelitian yang ditujukan untuk mendiskripsikan, menguji hubungan dan pengaruh antar peubah, mengacu pada hipotesis yang telah dirumuskan sebelumnya. Model teoritis yang akan diuji dalam penelitian ini meliputi bentuk hubungan antar peubah, yaitu hubungan peubah faktor kelembagaan X (Materi penyuluhan, Metode, Media, Waktu, Tempat, Suasana (kenyamanan), Persepsi penyuluh, Sikap penyuluh, Intensitas interaksi penyuluh, Kemampuan penyuluh) dengan peubah terikat yaitu partisipasi perempuan Y. Peubah dan sub peubah dalam penelitian ini diukur berdasarkan persepsi perempuan petani.

Penelitian dilakukan di Desa Suka Damai Kecamatan Dramaga Kabupaten Bogor. Penelitian dilakukan selama 2 bulan yaitu pada bulan November dan Desember 2011. Populasi dalam penelitian ini adalah perempuan yang bekerja sebagai petani. Pengambilan sampel responden dilakukan secara random. Jumlah sampel penelitian sebanyak 30 orang. Jenis data yang dikumpulkan terdiri dari data primer dan data sekunder. Data primer diperoleh melalui penggunaan kuisioner tertutup, wawancara dengan penggunaan kuisioner terbuka, dikusi kelompok terfokus (FGD), dan pengamatan.
Tahapan Analisis data terbagi dalam tahap deskripsi data dan tahap pengujian hipotesis.

\section{Hasil dan Pembahasan}

\section{Karakteristik Responden}

Perempuan petani tergolong pada usia produktif (rataan 47 tahun) dan belum didukung oleh tingkat pendidikan yang memadai. Responden yang tidak sekolah sebanyak $66,67 \%$. Hanya terdapat 8 orang responden $(26,67 \%)$ yang pernah mengikuti kegiatan penyuluhan pertanian yang diselenggarakan oleh PPL (Penyuluh PNS). Namun, hampir semua responden menyatakan bahwa mereka lebih sering mendapatkan informasi secara langsung dari Penyuluh Swadaya, yaitu petani maju yang sekaligus berperan sebagai pedagang pengumpul produk tanaman palawija. Rendahnya persentase responden yang mengikuti kegiatan penyuluhan yang difasilitasi oleh PPL disebabkan karena mereka yang menjadi anggota kelompok tani wanita hanya sedikit yaitu 3 orang (10\%) dan yang menjadi ketua kelompok 1 orang $(3,33 \%)$, dengan rata-rata lama menjadi anggota kelompok tani wanita sebesar 0,33 tahun. Padahal, di sisi lain pengalaman berusaha tani responden adalah rata-rata 19,53 tahun yang sebenarnya dapat diharapkan mendukung keberhasilan agribisnis petani, namun belum didukung oleh luas penguasaan lahan pertanian yang memadai. Diketahui rata-rata luas lahan hanya 0,22 hektar.

\section{Partisipasi Perempuan Petani dalam Kegiatan Pertanian Tanaman Palawija}

Partisipasi perempuan petani dalam kegiatan pertanian tanaman palawija adalah partisipasi perempuan pada tahap perencanaan, pelaksanaan, evaluasi, dan penerimaan manfaat atas partisipasinya dalam melakukan kegiatan pertanian tanaman palawija. Berdasarkan temuan penelitian, tingkat partisipasi perempuan pada ke empat tahapan tersebut tergolong "tinggi" (Tabel 1).

Pada tabel 1 tampak bahwa perempuan memiliki partisipasi yang tinggi artinya bahwa perempuan melakukan pekerjaan pertanian adalah lebih banyak dibandingkan laki-laki (suaminya) yang ditunjukkan dengan jumlah persentase sebesar 50\%. Penilaian tinggi terhadap partisipasi dan semua komponen manifesnya mengindikasikan bahwa perempuan mempunyai peranan dan tanggung jawab yang tinggi dalam hal 
Tabel 1 Sebaran Responden berdasarkan Kategori Partisipasi Perempuan pada Kegiatan Petanian Tanaman Palawija

\begin{tabular}{lcc}
\hline & Jml (orang) & Persen (\%) \\
\hline Sangat Rendah (Laki-laki) $=30-54$ & 0 & 0,00 \\
Rendah (Laki-laki $>$ Perempuan) $=55-79$ & 5 & 16,70 \\
Sedang (Laki-laki $=$ Perempuan) $=80-104$ & 5 & 16,70 \\
Tinggi (Perempuan $>$ Laki-laki) $=105-129$ & 15 & 50,00 \\
Sangat Tinggi (Perempuan) $=130-154$ & 5 & 16,70 \\
Total & 30 & 100,00 \\
Rata-rata & 105 & \\
Min-Max & $69,00-149,00$ & \\
\hline
\end{tabular}

produksi makanan bagi rumahtangganya dan bagi masyarakat. Temuan ini sejalan dengan apa yang telah dilakukan oleh peneliti-peneliti sebelumnya (Afzal, 2010; Chizari et al., 2003; Damisa et al., 2007; FAO, 2009; Sharon, 2008 dan Fabiyi et al., 2007 dalam Oladejo et al., 2011; Okafor C.N, 2008; Syamsiar, 2008; Taridala, 2010).

Bila dikaji lebih dalam, berdasarkan temuan lapangan diketahui bahwa partisipasi perempuan ternyata tidak hanya sebatas pada tahap pelaksanaan saja melainkan juga pada tahap perencanaan, pengawasan (Tabel 2). Bahkan terlihat bahwa skor partisipasi perempuan pada dimensi tahap perencanaan dan pengawasan adalah lebih tinggi dari dimensi tahap pelaksanaan. Fakta ini menunjukkan bahwa perempuan berperan dalam pengambilan keputusan-keputusan penting di dalam rumahtangga tentang pelaksanaan kegiatan pertanian dan pengawasannya. Misalnya keputusan tentang: kapan harus mengolah lahan, mengambil benih, menanam, menyiang, memupuk, mengendalikan hama penyakit; menggunakan jenis pupuk apa; mencari biaya untuk membeli pupuk; memutuskan jenis tanaman yang akan ditanam. Demikian pula halnya dengan dimensi tahap pengawasan. Perempuan petani melakukan kegiatan pengawasan pada kegiatan pertanian meskipun ia tidak melakukan pekerjaan itu. Hal ini sejalan dengan apa yang telah dilakukan oleh Okafor C.N (2008) dalam penelitiannya yang berjudul Women Participation In Agricutural Decision-Making In Aguata Local Government Area, Anambra State.

Lebih rendahnya skor partisipasi perempuan pada tahap pelaksanaan (Tabel 2) dibandingkan dengan skor pada dimensi perencanaan disebabkan karena terdapat pekerjaan pertanian yang tidak dilaksanakan oleh perempuan melainkan dilakukan oleh suami dan atau buruh tani. Jenis pekerjaan ini adalah pekerjaan pengolahan lahan dan penyiangan gulma.

Komponen yang mendukung tingginya partisipasi perempuan dalam kegiatan pertanian tanaman palawija adalah komponen perencanaan dan evaluasi, serta manfaat yang juga berada pada kategori tinggi. Berdasarkan temuan, meskipun perempuan mempunyai partisipasi yang tinggi dalam kegiatan pertanian tanaman palawija namun hanya sedikit $(33,33 \%)$ yang merasakan manfaat untuk dirinya sendiri. Manfaat terbesar $(66,66 \%)$ adalah dirasakan oleh keluarganya sebagai sumber nafkah bagi keluarga dan sumber bagi ketahanan pangan rumahtangga. Berdasarkan hasil wawancara tidak tersruktur dengan

Tabel 2 Analisis Deskriptif Skor Dimensi Partisipasi Perempuan dalam Kegiatan Pertanian Tanaman Palawija

\begin{tabular}{lccc}
\hline \multicolumn{1}{c}{ Partisipasi Perempuan } & Rata-rata & Minimum & Maksimum \\
\hline Perencanaan & 36,2 & 9 & 45 \\
Pelaksanaan & 23,7 & 13 & 45 \\
Pengawasan & 34,9 & 20 & 45 \\
Manfaat & 10,2 & 9 & 14 \\
\hline
\end{tabular}


Tabel 3 Sebaran Responden berdasarkan Kategori Partisipasi Perempuan pada Kegiatan Penyuluhan Pertanian Tanaman Palawija

\begin{tabular}{|c|c|c|}
\hline & $\begin{array}{c}\text { Jml. } \\
\text { (orang) }\end{array}$ & $\begin{array}{c}\text { Persen } \\
(\%)\end{array}$ \\
\hline Sangat Rendah & 4 & 13,3 \\
\hline Rendah & 16 & 53,3 \\
\hline Tinggi & 7 & 23,3 \\
\hline Sangat Tinggi & 3 & 10,0 \\
\hline Total & 30 & 100,0 \\
\hline Rata-rata & \multicolumn{2}{|c|}{29,87} \\
\hline Min-Max & \multicolumn{2}{|c|}{$13,00-47,00$} \\
\hline
\end{tabular}

responden ditemukan bahwa perempuan tidak hanya melakukan kegiatan pertanian saja melainkan juga melakukan berbagai kegiatan penanganan pasca panen dan pengolahan terhadap hasil usahataninya sebagai makanan bagi anggota rumahtangga dan kemudian mendistribusikan kepada anggota keluarga. Temuan ini sejalan dengan hasil penelitian yang dilakukan oleh Taridala (2010) dan Syamsiar (2008).

\section{Partisipasi Perempuan Petani dalam Kegiatan Penyuluhan Pertanian Tanaman Palawija}

Meskipun perempuan petani memiliki partisipasi yang tinggi dalam kegiatan pertanian tanaman palawija, hal ini tidak berarti bahwa partisipasi perempuan dalam kegiatan penyuluhan pertanian, khususnya yang dilakukan oleh PPL adalah tinggi. Tabel 3 menunjukkan bahwa partisipasi responden dalam kegiatan penyuluhan pertanian tergolong kategori rendah $(53,3 \%)$. Rendahnya kategori partisipasi perempuan pada kegiatan penyuluhan pertanian terkait dengan sedikitnya jumlah perempuan petani yang pernah mengikuti kegiatan penyuluhan pertanian di Desa Sukadamai. Data menunjukkan bahwa hanya terdapat 8 orang responden $(26,67 \%)$ yang pernah mengikuti kegiatan penyuluhan pertanian yang diselenggarakan oleh PPL (Penyuluh PNS). Ini pun dikarenakan mereka adalah perempuan yang menjadi anggota kelompok tani wanita yang jumlahnya hanya sedikit yaitu 3 orang (10\%) dan yang menjadi ketua kelompok 1 orang $(3,33 \%)$. Terkesan bahwa, penyuluh hanya mau melakukan komunikasi dengan perempuan petani yang menjadi pengurus dan atau anggota kelompok perempuan tani.

Komponen yang mendukung rendahya partisipasi perempuan dalam kegiatan penyuluhan pertanian adalah komponen perencanaan, pelaksanaan, pengawasan dan manfaat yang juga berada pada kategori rendah (Tabel 4). Rendahnya skor komponen pelaksanaan juga karena perempuan hanya terlibat sebagai peserta penyuluhan saja, tetapi rendah partisipasinya dalam hal kegiatan administrasi dan koordinasi (kategori sangat rendah 30\% dan rendah $46,67 \%$ ), serta kontribusi perempuan dalam pelaksanaan (kategori sangat rendah 20\% dan rendah 53,33\%).

Pada Tabel 4 tampak juga bahwa perolehan skor manfaat adalah lebih besar dari yang lainnya. Hal ini dikarenakan komponen manfaat adalah terdiri beberapa item komponen dan merupakan yang terbanyak penyumbang skor partsipasi dibandingkan komponen perencanaan, pelaksanaan, danevaluasi, Namundemikian, partisipasi perempuan dalam kegiatan penyuluhan pertanian telah dirasakan dapat memberikan manfaat bagi perempuan. Manfaat yang tertinggi dirasakan oleh perempuan adalah memperoleh manfaat secara sosial

Tabel 4 Analisis Deskriptif Skor Dimensi Partisipasi Perempuan dalam Kegiatan Penyuluhan Pertanian Tanaman Palawija

\begin{tabular}{lccc}
\hline Partisipasi Perempuan & Rata-rata & Minimum & Maksimum \\
\hline Perencanaan & 7,33 & 3 & 12 \\
Pelaksanaan & 5,93 & 3 & 12 \\
Pengawasan & 4,00 & 2 & 7 \\
Manfaat & 12,60 & 5 & 20 \\
\hline
\end{tabular}


Tabel 5 Hubungan antara Peubah Faktor yang Mempengaruhi Partisipasi Perempuan dalam Kegiatan Penyuluhan Pertanian

\begin{tabular}{lccccccc}
\hline & Materi & Metode & Media & Suasana & $\begin{array}{c}\text { Persepsi } \\
\text { penyuluh }\end{array}$ & $\begin{array}{c}\text { Sikap } \\
\text { penyuluh }\end{array}$ & $\begin{array}{c}\text { Kemampuan } \\
\text { penyuluh }\end{array}$ \\
\hline $\begin{array}{l}\text { Partisipasi perempuan dalam } \\
\text { penyuluhan }\end{array}$ & $0,530^{* *}$ & $0,606^{* *}$ & $0,625^{* *}$ & $0,464^{* *}$ & $0,567 * *$ & $0,580^{* *}$ & - \\
$\begin{array}{l}\text { Intensitas interaksi penyuluh } \\
\text { Persepsi penyuluh }\end{array}$ & - & - & - & - & - & - & $0,886^{* *}$ \\
\hline
\end{tabular}

Keterangan : $\quad * *$ Correlation is significant at the 0,01 level (2-tailed).

yaitu bertambahnya pengalaman dan meningkatnya pengetahuan dan keterampilan dengan kategori skor tinggi 33,33\% dan sangat tinggi 20\%. Meskipun rendah perolehan skornya, yang paling menarik dari sisi manfaat adalah perempuan memiliki kepercayaan diri dan kemantapan status sosial untuk berperan sebagai penyuluh swadaya bagi sesama perempuan petani dengan kategori skor tinggi $26,67 \%$ dan sangat tinggi $10 \%$.

Hal ini menunjukkan bahwa terdapat potensi untuk mengembangkan peranan perempuan petani sebagai penyuluh swadaya. Hal ini didukung dengan adanya pernyataan responden bahwa perempuan akan lebih nyaman jika belajar bersama penyuluh sawadaya perempuan dan akan lebih mudah melakukan komunikasi karena bertempat tinggal di desa.

\section{Kelembagaan Penyuluhan yang Berperan dalam Kegiatan Penyuluhan Pertanian Tanaman Palawija}

Berdasarkan temuan di lapangan kelembagaan penyuluhan yang diakui keberadaannya adalah PPL. Namun meskipun demikian, PPL dipandang oleh perempuan petani responden masih belum berperan dalam kegiatan penyuluhan pertanian tanaman palawija. Peran PPL selama ini digantikan oleh Penyuluh Swadaya, yaitu petani maju yang sekaligus berperan sebagai pedagang pengumpul produk tanaman palawija. Kegiatan Program Penyuluhan yang Berpengaruh terhadap Partisipasi Perempuan. Berdasarkan Tabel 5 tampak bahwa peubah partisipasi perempuan petani dalam penyuluhan pertanian mempunyai hubungan yang sangat kuat atau signifikan dengan peubah faktor yang mempengaruhi partisipasi perempuan dalam kegiatan penyuluhan pertanian (pada taraf nyata $\mathrm{p}<0,01$ ) yaitu dengan materi penyuluhan (koefisien korelasi sebesar 0,530), metode penyuluhan (koefisien korelasi sebesar 0,606 ), media penyuluhan (koefisien korelasi sebesar 0,625), suasana penyuluhan (koefisien korelasi sebesar 0,464), persepsi penyuluh tentang keberadaan perempuan sebagai petani dan partisipasi perempuan dalam kegiatan penyuluhan (koefisien korelasi sebesar 0,567), sikap penyuluh tentang kehadiran perempuan dan partisipasi aktif dalam kegiatan penyuluhan pertanian (koefisien korelasi sebesar 0,580).

Hal ini menunjukkan bahwa semakin meningkat kemampuan penyuluh dalam menentukan materi penyuluhan, metode penyuluhan, media penyuluhan yang sesuai dengan kebutuhan perempuan serta meningkatnya

Tabel 6 Analisa Regresi Linier Berganda Faktor-faktor Kelembagaan yang Mempengaruhi Partisipasi Perempuan dalam Kegiatan Penyuluhan Pertanian

\begin{tabular}{|c|c|c|c|c|c|}
\hline \multicolumn{2}{|c|}{ Peubah Tidak Bebas } & $\begin{array}{l}\text { Koefisien Tidak } \\
\text { Terstandarisasi }\end{array}$ & $\begin{array}{c}\text { Koefisien } \\
\text { Terstandarisasi } \\
\end{array}$ & $\mathbf{T}$ & Sig \\
\hline \multicolumn{2}{|l|}{ Konstanta } & B & Beta & & \\
\hline \multicolumn{2}{|l|}{ Metode } & 2,415 & 0,557 & 3,358 & 0,003 \\
\hline \multicolumn{2}{|l|}{ Sikap } & 2,765 & 0,445 & 2,960 & 0,007 \\
\hline \multicolumn{2}{|c|}{ Intensitas interaksi penyuluh } & 2,903 & 0,358 & 1,216 & 0,235 \\
\hline \multicolumn{2}{|c|}{ Kemampuan penyuluh } & $-3,176$ & $-0,475$ & $-1,466$ & 0,155 \\
\hline Nilai Adjusted & 0,482 & & & & \\
\hline Nilai F Hitung & 6,027 & & & & \\
\hline Sig F & 0,001 & & & & \\
\hline
\end{tabular}


kemampuan penyuluh dalam menciptakan suasana penyuluhan yang nyaman dan menyenangkan maka semakin meningkat pula partisipasi perempuan dalam penyuluhan pertanian.

Hubungan antara peubah faktor yang mempengaruhi partisipasi perempuan dalam kegiatan penyuluhan pertanian menunjukkan bahwa peubah intensitas interaksi penyuluh dengan perempuan petani mempunyai hubungan atau korelasi yang sangat significant dengan peubah kemampuan penyuluh. Kuatnya hubungan antara peubah ini dapat ditunjukkan dengan perolehan koefisien korelasi pada taraf nyata 0,01 yaitu sebesar 0,886 . Hal ini menunjukkan bahwa semakin meningkat kemampuan teknis dan non-teknis penyuluh, mengunjungi perempuan petani secara teratur dan semakin meningkat kemampuan penyuluh dalam hal membantu perempuan petani mencari solusi atas permasalahan yang dihadapi maka semakin aktif penyuluh membangun komunikasi dengan perempuan petani dan membangun kesepakatan jadwal pertemuan periodik antara penyuluh dan perempuan petani.

Selain itu, hubungan yang sangat kuat antara peubah persepsi penyuluh tentang keberadaan perempuan sebagai petani dan partisipasi perempuan dalam kegiatan penyuluhan dengan peubah sikap penyuluh tentang kehadiran perempuan dan partisipasi aktif dalam kegiatan penyuluhan pertanian (koefisien korelasi sebesar 0,712). Hal ini menunjukkan bahwa semakin positif persepsi penyuluh tentang keberadaan perempuan sebagai petani dan partisipasi perempuan dalam kegiatan penyuluhan maka semakin tinggi sikap penyuluh tentang kehadiran perempuan dan partisipasi aktif dalam kegiatan penyuluhan pertanian.

Memperhatikan keterkaitan antara peubah kemampuan penyuluh dan intensitas interaksi penyuluh jelas bahwa semakin kuat hubungan di antaranya menunjukkan semakin kuatnya jalinan komunikasi atau interaksi antara PPL dengan perempuan petani. Sedangkan, keterkaitan antara peubah persepsi dan sikap jelas bahwa semakin kuat hubungan diantaranya menunjukkan semakin tinggi komitmen penyuluh dan kesadaran jender PPL untuk meningkatkan partisipasi perempuan dalam kegiatan penyuluhan pertanian.

Namun, hasil analisis regresi terhadap peubah faktor kemampuan penyuluh dalam melaksanakan penyuluhan yang mempengaruhipartisipasi perempuan dalam kegiatan penyuluhan memberikan hasil bahwa peubah metode dan sikap penyuluh $(\mathrm{p}<0,05)$ yang berpengaruh secara nyata. Semakin tepat atau sesuai penggunaan metode penyuluhan dengan kebutuhan perempuan maka akan semakin tinggi tingkat partisipasi perempuan dalam kegiatan penyu-luhan pertanian. Temuan ini sejalan dengan temuan penelitian yang dilakukan oleh Pini (2002) dan Mudukuti (2002). Semakin positif sikap penyuluh terhadap partisipasi perempuan dalam kegiatan penyuluhan pertanian maka semakin tinggi tingkat partisipasi perempuan dalam kegiatan penyuluhan pertanian. Hal ini sejalan dengan temuan penelitian yang dilakukan oleh Afzal (2010), FAO (2009), Sharon (2008) dan Fabiyi et al. (2007) dalam Oladejo et al. (2011).

\section{Kesimpulan}

Berdasarkan tujuan penelitian dan uraian di atas dapat disimpulkan bahwa partisipasi perempuan petani pada kegiatan pertanian tanaman palawija adalah dalam kategori tinggi (53,3\%) yang dapat dilihat pada komponen perencanaan, pelaksanaan, evaluasi dan manfaat. Namun, hal ini tidak diiringi dengan tingginya partisipasi perempuan petani pada kegiatan penyuluhan pertanian tanaman pangan. Hasil penelitian menunjukkan bahwa partisipasi perempuan petani dalam kegiatan penyuluhan pertanian dalam kategori rendah (50\%). Hal ini disebabkan karena faktor sikap penyuluh yang tidak positif atau sangat rendah terhadap partisipasi perempuan dalam kegiatan penyuluhan pertanian. Hasil analisis regresi menunjukkan bahwa sikap penyuluh terhadap kehadiran perempuan sebagai peserta penyuluhan dan partisipasi aktif perempuan dalam kegiatan penyuluhan berpengaruh secara nyata $(\mathrm{p}<0,05)$ terhadap partisipasi perempuan dalam kegiatan penyuluhan pertanian. Keberadaan kelembagaan penyuluhan BP3K Kecamatan Dramaga masih dirasakan merupakan lembaga penyuluhan yang penting bagi perempuan, namun harus diimbangi dengan peningkatan kinerja penyuluh lapangannya. Karena, keberadaan penyuluh swadaya di Desa Sukadamai juga mempunyai peranan penting dalam mentransfer inovasi kepada petani.

Semakin meningkat kemampuan penyuluh dalam menentukan materi penyuluhan, metode penyuluhan, media-media penyuluhan yang sesuai dengan kebutuhan perempuan serta meningkatnya kemampuan penyuluh dalam menciptakan suasana penyuluhan yang nyaman dan menyenangkan maka semakin meningkat pula partisipasi perempuan dalam penyuluhan pertanian. Selain itu, hubungan yang 
sangat kuat antara peubah persepsi penyuluh tentang keberadaan perempuan sebagai petani dan partisipasi perempuan dalam kegiatan penyuluhan dengan peubah sikap penyuluh tentang kehadiran perempuan dan partisipasi aktif dalam kegiatan penyuluhan pertanian

Oleh karena itu, perlu dibangun dan ditumbuhkan kesadaran gender baru dan juga komitmen yang tinggi dari PPL untuk meningkatkan partisipasi perempuan dalam kegiatan penyuluhan pertanian, serta perlunya merancang strategi peningkatan partisipasi perempuan dalam kegiatan penyuluhan pertanan.

\section{Daftar Pustaka}

Anonymous. 2009. Gender in Agricultural Innovation and Education. Gender in Agriculture Sourcebook. The World Bank, FAO, IFAD. Washington, DC.

Cohen J, Uphoff N. 1980. Participation place in rural development : seeking clarity trough Specificity. J. World Development.

FAO. 1996. Women in Agricultural and Rural Development. Rome, FAO.

Hayati. 2000. Perempuan petani dan kegiatan penyuluhan pertanian tanaman pangan di dua desa di Kabupaten Lombok Barat. (Kasus di desa lahan basah dan lahan kering). [tesis]. Jakarta (ID): Universitas Indonesia.

Hayati. 2003. Kajian Model Penyuluhan Pertanian yang Berperspektif Jender di Kabupaten Lombok Barat. Kerjasama PSW Universitas Mataram dengan Proyek DAFEP Kabupaten Lombok Barat, NTB.

LEISA Editorial. 2000. Newsletter for Low External Input and Sustainable Agriculture (LEISA). Leusden, The Netherlands 16(4). Desember 2000.

Ndraha T. 1990. Pembangunan Masyarakat. Jakarta : Rineka Cipta. Palupi, Woro Dyah Edining .1998. Wanita dan teknologi pertanian. Jurnal Media Wanita dan Pembangunan 1(2): 3,12,17.

Palupi, Edining WD. 1998. Wanita dan teknologi pertanian. Jurnal Media Wanita dan Pembangunan 1(2): 3,12,17.

RogerEM, danFF Shoemaker. 1971. Communication of Inovations. A Cross Cultural Approach. New York: A Division of The Macmillan Company.
Roger EM. 1994. The Diffussion Process. New York: The Free Press.

Sahidu A. 1998. "Partisipasi masyarakat tani pengguna lahan sawah dalam pembangunan pertanian di daerah Lombok, NTB.” [Disertasi]. Bogor (ID): Program Pascasarjana IPB.

Slamet M. 2003. "Meningkatkan Pertisipasi Masyarakat dalam Pembangunan Perdesaan." Di dalam Membentuk Pola Prilaku Manusia Pembangunan. Diedit oleh Sudrajad dan Yustina. Bogor (ID): IPB Press.

Supartiningsih, Hanartani, Irwan. 1997. Analisis jender usaha tani tanaman pangan di Kabupaten Lombok Tengah. Laporan Penelitian tidak di terbitkan. Mataram (ID): Pusat Studi Wanita Universitas Mataram.

Syamsiar. 2008. Model Ketahanan Pangan Rumah Tangga Melalui Kearifan Lokal (Suatu Studi Pengelolaan Lahan Pasir Di Depok, Desa Parangtritis, Kecamatan Kretek, Kabupaten Bantul, Provinsi DIY). Jurnal Dinamika Sosial Ekonomi (JDSE).

Sangadji. 2010. Partisipasi Masyarakat dalam Pengelolaan Taman Nasional dengan Pola kemitraan di Kepulauan Togean Sulawesi Tengah [disertasi]. Bogor (ID): Program Pascasarjana IPB.

Surayasa, Tusan M. 1998. Wanita dan pembangunan pertanian: Suatu analisis jender pada proyek pembangunan pertanian rakyat terpadu (P2RT) di Kabupaten Buleleng, Bali. [tesis]. Jakarta (ID): Universitas Indonesia.

Taradila. 2010. "Analisis Peran Gender dalam Pencapaian Ketahanan Pangan Rumahtangga Petani di Kabupaten Konowe Selatan Provinsi Su;awesi Tenggara" [Disertasi]. Bogor (ID): Program Pascasarjana IPB.

The World Bank. 2009. Gender Issues in Agricultural Labor: Gender in Agriculture Sourcebook. World Bank, Washington DC.

Agbogidi. 2009. Extension And Forestry Development Training For Rural Women On Forest Exploitation. ARPN Journal of Agricultural and Biological Science 4(5). [Internet]. [dapat diunduh dari: http:// arpnjournals .com]

Akeredolu. 2009. Female Students' Participation in the University Mid-Career Agricultural Extension Training Programme in West 
Africa: Constraints and Challenges. Journal of International Agricultural and Extension Education. [Internet]. [dapat diunduh dari: http://www.aiaee.org]

Afzal. 2010. Women Empowernment in Agricultural Decision Making and Their Participation in Extension Work. [Internet]. [dapat diunduh dari: http:/proquest.umi.com]

Akeredolu. 2009. Female Students' Participation in the University Mid-Career Agricultural Extension Training Programme in West Africa: Constraints and Challenges. Journal of Inter national Agricultural and Extension Education. [Internet]. [dapat diunduh dari: http://www. aiaee.org]

Barbercheck M et al. 2009. Meeting the Extension Needs of Women Farmers: A Perspective from Pennsylvania. Journal of Extention 47(3). [Internet]. [dapat diunduh dari: http://www.joe. org]

Chizari M, Lindner JR, Bashardoost R. 1997. Participation of Rural Women in Rice Production Activities and Extension Programs in The Gilan Province, Iran. Journal of International Agricultural and Extension Education 4(3). [Internet]. [dapat diunduh dari: http://www. aiaee.org].

Damisa MA, Samndi R, Yohanna M. 2007. Women Participation in Agricultural Production: A Probit Analysis. Journal of Applied Science. 7(3): 412-416. [Internet]. [dapat diunduh dari: http://adsabs.harvard.edu].

Elizabeth S 2007. Agricultural information needs of women farmers in Mubi region, Adamawa State. Journal of Tropical Agriculture. 45(1-2): 69-71. [Internet]. [dapat diunduh dari: http// www.jtropag.in].

Flynn, Frick, dan Steele. 2010. Relationship Between Participation in 4-H and Community Leadership in Rural Montana. Journal of Extension. 48 (2). [Internet]. [dapat diunduh dari: http://www.joe. org].

Goff S, Lindner JR, and Doly D. 2008. Factors in Participation and Non-Participation in Farmer Field Schools in Trinidad and Tobago. Journal of International Agricultural and Extension Education. [Internet]. [dapat diunduh dari: http://www.aiaee.org].

Jiggins J et al. 1997. Improving Women Farmers'
Access to Extension Services, (artikel on Line), [Internet]. [dapat diunduh dari: http://www.fao. org].

Mudukuti A. 2002. Factors Related to Zimbabwe Women's Educational Needs in Agriculture, Journal of International Agricultural and Extension Education. 9(3). [Internet]. [dapat diunduh dari: http://www.aiaee.org]

Okafor CN. 2008. Women Participation In Agricutural Decision-Making In Aguata Local Governmmment Area, Anambra State. Journal of Agricultural Extension. 12(2).

Oladejo, Olawuyi SO, Anjorin TD. 2011. Analysis of Women Participation in Agricultural Production in Egbedore Local. International Journal of Agricultural Economics \& Rural Development. 4(1). [Internet]. [dapat diunduh dari: http:// www.ijaerd.lautechaeeedu.com]

Pini. 2002. Consraints to Women's Involvement in Agricultural Leadership. Women in Management Review. 17(6). [Internet]. [dapat diunduh dari http://www.emeraldinsight.com]

Richardson JG et al. 2003. Barriers to Participation in Extension Expanded Foods and Nutrition Programs. Journal of Extention. 41(4). [Internet]. [dapat diunduh dari: http://www.joe. org]

Rivera. 1990. Empowering Women Through Agricultural Extension: A Global Perspective. Journal of Extension, 28(4). [Internet]. [dapat diunduh dari: http://www.joe.org]

Shibanda, Seru. 2002. Human Resource Strategy for Kenyan Women Smallholders. Women in Management Review. 17(5-6). [Internet]. [dapat diunduh dari: http:/proquest.umi.com]

Squire PJ. 2003. Strategies for Enhancing Women's Full Participation in Sustainable Agricultural. Journal of International Agricultural and Extension Education. 10(1). [Internet]. [dapat diunduh dari: http:// www.aiaee.org].

Strong, Harder. 2011. Motivational Orientations of Adults Participating in a Cooperative Extension Master Gardener Program. Journal of Extention. 48(4). [Internet]. [dapat diunduh dari :http:// www.joe.org]

Vatta et al. 2008. Participation of Zulu Farmers in a Goat Health Research and Extension Project in South Africa. Journal of International Agricultural and Extension Education. 15(3). 
Jurnal Penyuluhan, September 2013 Vol. 9 No. 2

[Internet]. [dapat diunduh dari: http://www. Yazdani et al.2011. Cultural Development and Women aiaee.org] Participation: A Review on Organizational Factors. Interdisciplinary Journal of Contemporary Research In Business. 3(2). [Internet]. [dapat diunduh dari: http://www.allbusiness.com] 